\title{
Effects of plant height on population dynamics of Wheat crop (Triticum aestivum L.)
}

\author{
Abdul Hameed Baloch ${ }^{1 *}$, Muslim Qadir ${ }^{1,2}$, Haneef-Ur-Rehman ${ }^{3}$, Noor \\ Muhammad $^{1}$ and Shaik Abdullah ${ }^{4}$ \\ 1. Faculty of Agriculture, Lasbela University of Agriculture, Water and Marine sciences (LUAWMS) Lasbela \\ 74200, Balochistan-Pakistan \\ 2. Oil Crops Research Institute of the Chinese Academy of Agricultural Sciences (CAAS), Wuhan 430063, Hubei, \\ People's Republic of China \\ 3. University of Turbat, Kech, Balochistan-Pakistan \\ 4. Faculty of Water Resources Management, Lasbela University of Agriculture, Water and Marine sciences \\ (LUAWMS) Lasbela 74200, Balochistan-Pakistan \\ *Corresponding author's email: msmirwani22@gmail.com \\ Citation \\ Abdul Hameed Baloch, Muslim Qadir, Haneef-Ur-Rehman, Noor Muhammad1 and Shaik Abdullah. Effects of plant \\ height on population dynamics of Wheat crop (Triticum aestivum L.). Pure and Applied Biology. Vol. 9, Issue 4, \\ pp2628-2636. http://dx.doi.org/10.19045/bspab.2020.90279
}

\begin{tabular}{llll}
\hline \hline Received: 06/04/2020 & Revised: 27/07/2020 & Accepted: 07/08/2020 & Online First: 17/08/2020 \\
\hline
\end{tabular}

\section{Abstract}

The wheat (Triticum aestivum L.) is an important staples crop of Pakistan and the Central Asia. The present research is an effort to clarify the super wheat genotypes, which were carried out at the experimental field area of Lasbela University of Agriculture, Water and Marine Sciences (LUAWMS), Pakistan, in order to study the effect of intra-specific competition on individual plants of Wheat (variety Sahar 2006) during the 2013-2014 wheat growing season. The experiment was carried out in a randomized complete block design comprising of two rows spacing (15 and $30 \mathrm{~cm}$ ) and broadcasting method of seeding with four replicates at a 30 days' interval by destruction method. Final harvest was carried out at the end of growing season (150 days after seeding). The agronomic characteristics of wheat have shown non-significant response for effect of row spacing at final harvest. However, application of Gini Coefficient and Lorenz Curve clearly indicated the inequalities in plant height, number and length of spike and spikelet among the individual plants. The Gini values are more pronounced at mid-season harvest compared with final harvest. The results of present study explained the reasons of inequality in plant height and growth within the pure-line of wheat crop.

Keywords: Gini Coefficient; Lorenz Curve; Physiological traits; Row spacing; Wheat

\section{Introduction}

Wheat crop belong from the Poaceae family, is a self-pollinated and the most imperative cereal crop of the world. It is a staple food and gives almost $35 \%$ of food as consumed by the world population $[1,2]$. Wheat is the most widely cultivated food crop of the globe. Its adaptation to different climatic situations is a key and to create it a remarkable crop; which has significant role in world economy. It is thought to have initiated on the Eurasian continent, a 
beginning point from wherever man spread it throughout the world, including China and central Europe [3]. Wheat is providing 68\% of vitality and stands second among cereal crops with respect to Asia and further particularly in the south Asian region [4]. Wheat is the cheapest source of calories, protein, and carbohydrates in human diet. It is grown as a rain-fed as well as flooded grown crop $[1,5]$.

Row spacing and plant density per unit area are important agronomic practices for the production of wheat grown under rain-fed agrarian areas. Row-spacing and plant density received attention over the last several decades and it has been widely documented and understood previously that narrow row-spacing can be resulted in an increased plant competition to affect yield adversely [6]. According to Ghaffar et al. [7] grain yield per unit area is inversely proportion to plant row-spacing in which decreased row spacing have contributed to increase grain yield per unit area. Wheat grain can be defined as the combined product of the number of spike and the average weight of grain of spikes. However, there is paucity of scientific understanding of competitive ability in relation with rowspacing. In this regard most of our understanding emphasized on relationships between competitive outcomes (final yield) and a small number of determined traits [8]. Extent of individual plant competition varies during the growing season and is dependent upon various biological and environmental factors such as availability of resources and number of individuals acquiring these resources [9].

Height inequality among plants involves an exertion for limited resources i.e. sunlight, water, and for soil nutrients. Interaction based on size inequality, among the neighboring individuals in population restricted the reproductive output of comparatively vulnerable individuals compared with strong ones [10]. Competition for limiting resources among neighboring plants resulted into height hierarchies of population over time [10].

In Pakistan, wheat (Triticum aestivum L.) is considered a major cultivated area is devoted to wheat and occupies i.e $70 \%$ of Rabi and $37 \%$ of total cropping area [11]. Although the environmental conditions in Pakistan are very conducive for wheat cultivation, it is per hectare yield $(2166.8 \mathrm{~kg})$ is still less than many agriculturally advanced countries of the world [7]. Wheat is the leading food grain of Pakistan occupying the largest area under single crop and contributes $10.0 \%$ to the value added in agriculture and 2.1 percent to GDP. Rain-fed wheat accounts $20 \%$ area in Pakistan [12]. Wheat area under cultivation is nearly 382,940 hectares with 871,300 of production tones/year in Baluchistan $[1,13]$. Baluchistan, the largest but least populated province of Pakistan faces challenges relevant with water scarcity.

The purpose of research was to improve understanding of the dynamics of size forming in crop species, studying its association with size dependent growth. The new system is based on various significant mechanisms. A number of factors including insect pest attack, weed infestation, use of poor quality seed, and low soil fertility, may be attributed to this yield gap. The current study focused on the effect of row-spacing on variability in plant height, biomass, spike number, and spike length, during the winter season of 2013-14. The consideration is focused on the development of size inequality, effect of plant height and its relationship with reproductive success.

\section{Materials and methods}

Wheat (Triticum aestivum L. variety Seher2006) was grown under well-irrigated experimental fields of LUAWMS, District Lasbela, during the growing seasons of November to April in 2013-14. Plants were irrigated with flood method and were 
inundated with water once a week during the experiment. The experiments were conducted under randomized complete block design (RCBD) having 4 replications. The experimental unit (plot) was kept $5 \times 10 \mathrm{~m}$ and on each plot 2 sets of four quadrates of 1 $\times 1 \mathrm{~m}^{2}$ were maintained. The seeds of Sehar2006 were sown@180 kg ha-1 by hand into 15 and $30 \mathrm{~cm}$ rows as well as by broadcasting method at the end of November, 2011 [14]. Harvesting was done at the end of April, 2014. Data were recorded during an interval of 30 days after the first emergence of seedling till the final harvest [15].

During each monthly visit five individual plants were selected in subplots by destructing methods and following data were recorded, plant height $(\mathrm{cm})$ number and length of leaf blade $(\mathrm{cm})$, number of tillers, number of flowering buds, dry biomass and reproductive biomass (gm).

The effect of intraspecific competition among the individual wheat plants were determined by least significant difference (LSD) tests. The results for analysis of variance have been considered significant if P-values were $<0.05$ [16]. The skewedness and kurtosis of the data were determined with SPSS (IBM 2011). Skewedness evaluates the degree of variability for different frequency distributions [17]. Positive and negative values of skewedness are defined as Lshaped and J-shaped distributions, respectively. Zero skewedness suggests a symmetrical distribution within a population
[17]. According to Nagashima et al. [18] shows the peakedness of the frequency distribution and positive or negative values of kurtosis implied, as the distribution is more peaked (leptokurtic) or bimodal (platykurtic). The variability among wheat for plants height as well as reproductive biomass was assessed by using the method Lorenz curve as well as Gini coefficient given by Weiner and Solberg, [19]. The Lorenz curve provides the detailed structure of size inequality and allows one to identify the regions where significant size differences occur. Using the Lorenz curve, individual plants have been categorized in increasing order with respect to the parameter measured. The cumulative fractions of individual plants $(p)$ have been plotted considering the cumulative fraction of dependent variable L (p) such as plant height $[20,21]$. This curve corresponding with $p$ and $\mathrm{L}(\mathrm{p})$ ranged from [po, L (po)], [p1, L(p1)], [pk, L( pk )], [pk $+1=\mathrm{L}(\mathrm{pk}+1)]$, having $\mathrm{po}=\mathrm{L}(\mathrm{po})=0$ whereas $\mathrm{pk}+1=\mathrm{L}(\mathrm{pk}+1)$ $=1$. Specifically, the value of the Gini coefficient is equal to twice the area between $\mathrm{L}(\mathrm{p})$ and the 450 line equality [21].

The Gini coefficient has been considered to have a minimum value $=0$, as whole plants under study have similar height for example, whereas the maximum value of 1.0 is considered to be having an infinite population for all individuals, where one individual have a value of 0 as described by Weiner and Solberg [19]. Gini coefficient (G) is given by the following equation:

$$
G=\frac{1}{2 \bar{x} n(n-1)} \sum_{i=1}^{n}(2 i-n-1) X_{i}
$$

Where, Here $\mathrm{n}$ plants are having a mean height of $\mathrm{x}, \mathrm{Xi}$ are sizes sorted from smallest to largest $\mathrm{X} 1 \leq \mathrm{X} 2 \leq \ldots . . \mathrm{Xn}$., (Weiner and Solberg [19, 22, 23].

\section{Results and discussion}

The results of present study showed significant spatial-temporal variations in plant height, number of tillers, biomass and reproductive output in $1 \mathrm{~m}-1$ subplot (Table $1 a, b, c)$. The treatment having row spacing $=15 \mathrm{~cm}$ found to produce higher biomass as compared with a row spacing $=$ of $30 \mathrm{~cm}$ with broadcasting method. Although at early growth stages, differences of biomass 
accumulation in wheat plants in three row spacing were minimal, but as plant growth progress, $15-\mathrm{cm}$ row spacing showed higher biomass accumulation compared with $30-\mathrm{cm}$ row spacing and broad casting methods. These results agreed with Chen et al. [24] who recorded a substantial decrease in plant Table 1(a). Effect of Wheat Row Spacing $(15 \mathrm{~cm})$ on plant height, number of tiller, number of leaf, leaf size, biomass and reproductive biomass during four successive visits

\begin{tabular}{|c|c|c|c|c|c|c|c|}
\hline $\begin{array}{c}\text { Visit } \\
\text { s }\end{array}$ & $\begin{array}{c}\text { Height } \\
(\mathbf{c m})\end{array}$ & $\begin{array}{c}\text { No. of } \\
\text { tillers }\end{array}$ & No. of leaf & $\begin{array}{c}\text { Leaf } \\
\text { length } \\
(\mathbf{c m})\end{array}$ & $\begin{array}{c}\text { Biomass } \\
(\mathbf{g m})\end{array}$ & $\begin{array}{c}\text { No. of } \\
\text { spike }\end{array}$ & $\begin{array}{c}\text { Reproductiv } \\
\text { e biomass } \\
(\mathbf{g m})\end{array}$ \\
\hline $\begin{array}{c}30 \\
\mathrm{DAE}\end{array}$ & $\begin{array}{c}29.00 \pm 0.57 \\
\mathrm{a}\end{array}$ & $3.0 \pm 0^{\mathrm{a}}$ & $12.66 \pm 2.02^{\mathrm{a}}$ & $\begin{array}{c}11.16 \pm 0.38 \\
\mathrm{a}\end{array}$ & $0.63 \pm 0.22^{\mathrm{a}}$ & $0.0 \pm 0.0^{\mathrm{a}}$ & $0.0 \pm 0.0^{\mathrm{a}}$ \\
\hline $\begin{array}{c}40 \\
\mathrm{DAE}\end{array}$ & $\begin{array}{c}49.33 \pm 3.52 \\
\mathrm{~b}\end{array}$ & $3.33 \pm 0.33^{\mathrm{a}}$ & $16.33 \pm 1.76^{\mathrm{a}}$ & $\begin{array}{c}10.07 \pm 1.10 \\
\mathrm{a}\end{array}$ & $1.68 \pm 0.30^{\mathrm{a}}$ & $1.0 \pm 0.0^{\mathrm{a}}$ & $0.33 \pm 0.4^{\mathrm{a}}$ \\
\hline $\begin{array}{c}90 \\
\text { DAE }\end{array}$ & $\begin{array}{c}85.66 \pm 4.48 \\
\mathrm{c}\end{array}$ & $\begin{array}{c}14.33 \pm 3.92 \\
\mathrm{~b}\end{array}$ & $\begin{array}{c}42.66 \pm 12.73 \\
\mathrm{~b}\end{array}$ & $\begin{array}{c}13.87 \pm 1.09 \\
\mathrm{~b}\end{array}$ & $\begin{array}{c}64.15 \pm 42.94 \\
\mathrm{~b}\end{array}$ & $\begin{array}{c}13.00 \pm 4.93 \\
\mathrm{~b}\end{array}$ & $34.28 \pm 22.58^{\mathrm{b}}$ \\
\hline $\begin{array}{c}120 \\
\mathrm{DAE}\end{array}$ & $\begin{array}{c}75.50 \pm 3.96 \\
\mathrm{c}\end{array}$ & $\begin{array}{c}11.33 \pm 1.85 \\
\mathrm{~b}\end{array}$ & $0.0 \pm 0.0^{\mathrm{a}}$ & $0.0 \pm 0.0^{\mathrm{c}}$ & $9.53 \pm 1.16^{\mathrm{ab}}$ & $\begin{array}{c}10.66 \pm 2.33 \\
\mathrm{~b}\end{array}$ & $15.30 \pm 3.08^{\mathrm{ab}}$ \\
\hline
\end{tabular}

Different letters in a column indicate significant differences at $p<0.05$. DAE $=$ days after emergence. Values in each column indicate mean values with standard errors

Table 1(b). Effect of Wheat Row Spacing $(30 \mathrm{~cm})$ on plant height, number of tiller, number of leaf, leaf size, biomass and reproductive biomass during four successive visits

\begin{tabular}{|c|c|c|c|c|c|c|c|}
\hline Visits & $\begin{array}{c}\text { Height } \\
(\mathbf{c m})\end{array}$ & $\begin{array}{c}\text { No. of } \\
\text { tillers }\end{array}$ & No. of leaf & $\begin{array}{c}\text { Leaf length } \\
(\mathbf{c m})\end{array}$ & $\begin{array}{c}\text { Biomass } \\
(\mathbf{g m})\end{array}$ & $\begin{array}{c}\text { No. of } \\
\text { spike }\end{array}$ & $\begin{array}{c}\text { Reproductive } \\
\text { biomass }(\mathbf{g m})\end{array}$ \\
\hline $\begin{array}{c}30 \\
\text { DAE }\end{array}$ & $25.00 \pm 1.52^{\mathrm{a}}$ & $3.66 \pm 0.33^{\mathrm{a}}$ & $13.66 \pm 1.85^{\mathrm{a}}$ & $10.07 \pm 1.84^{\mathrm{a}}$ & $0.45 \pm 0.04^{\mathrm{a}}$ & $0.0 \pm 0.0^{\mathrm{a}}$ & $0.0 \pm 0.0^{\mathrm{a}}$ \\
\hline $\begin{array}{c}60 \\
\text { DAE }\end{array}$ & $43.33 \pm 1.45^{\mathrm{b}}$ & $11.33 \pm 3.71^{\mathrm{b}}$ & $49.66 \pm 15.16^{\mathrm{b}}$ & $10.74 \pm 0.38^{\mathrm{a}}$ & $4.38 \pm 0.9^{\mathrm{a}}$ & $0.33 \pm 0.33^{\mathrm{a}}$ & $0.15 \pm 0.15^{\mathrm{a}}$ \\
\hline $\begin{array}{c}90 \\
\text { DAE }\end{array}$ & $88.00 \pm 2.08^{\mathrm{c}}$ & $12.33 \pm 0.88^{\mathrm{bc}}$ & $29.66 \pm 0.88^{\mathrm{ab}}$ & $17.25 \pm 0.11^{\mathrm{b}}$ & $21.78 \pm 1.3^{\mathrm{b}}$ & $10.33 \pm 1.85^{\mathrm{b}}$ & $13.95 \pm 2.16^{\mathrm{b}}$ \\
\hline $\begin{array}{c}120 \\
\text { DAE }\end{array}$ & $80 \pm 4.35^{\mathrm{c}}$ & $8.66 \pm 1.66^{\mathrm{abc}}$ & $0.00 \pm 0.00^{\mathrm{ac}}$ & $0.00 \pm 0.00^{\mathrm{c}}$ & $12.03 \pm 3.6^{\mathrm{c}}$ & $8.33 \pm 1.85^{\mathrm{b}}$ & $12.03 \pm 3.6^{\mathrm{b}}$ \\
\hline
\end{tabular}

Different letters in a column indicate significant differences at $p<0.05$. DAE $=$ days after emergence. Values in each column indicate mean values with standard errors

Table 1(c). Effect of Wheat Row Spacing (broadcasting method) on plant height, number of tiller, number of leaf, leaf size, biomass and reproductive biomass during four successive visits

\begin{tabular}{|c|c|c|c|c|c|c|c|}
\hline Visits & $\begin{array}{c}\text { Height } \\
(\mathbf{c m})\end{array}$ & $\begin{array}{c}\text { No. of } \\
\text { tillers }\end{array}$ & No. of leaf & $\begin{array}{c}\text { Leaf length } \\
(\mathbf{c m})\end{array}$ & $\begin{array}{c}\text { Biomass } \\
(\mathbf{g m})\end{array}$ & $\begin{array}{c}\text { No. of } \\
\text { spike }\end{array}$ & $\begin{array}{c}\text { Reproductive } \\
\text { biomass }(\mathbf{g m})\end{array}$ \\
\hline $\begin{array}{c}30 \\
\text { DAE }\end{array}$ & $23.83 \pm 0.16^{\mathrm{a}}$ & $2.33 \pm 0.88^{\mathrm{a}}$ & $8.33 \pm 2.6^{\mathrm{a}}$ & $10.03 \pm 1.67^{\mathrm{a}}$ & $0.27 \pm 0.07^{\mathrm{a}}$ & $0.00 \pm 0.00^{\mathrm{a}}$ & $0.00 \pm 0.00^{\mathrm{a}}$ \\
\hline $\begin{array}{c}60 \\
\text { DAE }\end{array}$ & $32.66 \pm 2.72^{\mathrm{b}}$ & $8.66 \pm 1.66^{\mathrm{b}}$ & $33.66 \pm 8.83^{\mathrm{b}}$ & $11.17 \pm 1.11^{\mathrm{a}}$ & $3.45 \pm 0.74^{\mathrm{a}}$ & $0.00 \pm 0.00^{\mathrm{a}}$ & $0.00 \pm 0.00^{\mathrm{a}}$ \\
\hline $\begin{array}{c}90 \\
\text { DAE }\end{array}$ & $77.33 \pm 3.71^{\mathrm{c}}$ & $5.33 \pm 0.88^{\mathrm{ab}}$ & $15.0 \pm 2.0^{\mathrm{a}}$ & $18.27 \pm 0.69^{\mathrm{b}}$ & $9.38 \pm 0.93^{\mathrm{b}}$ & $4.33 \pm 0.33^{\mathrm{b}}$ & $8.41 \pm 1.55^{\mathrm{b}}$ \\
\hline $\begin{array}{c}120 \\
\text { DAE }\end{array}$ & $78.66 \pm 2.66^{\mathrm{c}}$ & $6.66 \pm 1.2 \mathrm{~b}^{\mathrm{c}}$ & $0.00 \pm 0.00^{\mathrm{a}}$ & $0.00 \pm 0.00^{\mathrm{c}}$ & $8.76 \pm 2.14^{\mathrm{b}}$ & $6.66 \pm 0.88^{\mathrm{c}}$ & $17.55 \pm 4.21^{\mathrm{c}}$ \\
\hline
\end{tabular}

Different letters in a column indicate significant differences at $p<0.05$. DAE $=$ days after emergence. Values in each column indicate mean values with standard errors 
The higher biomass and number of tillers per plant have been found in row spacing of $15 \mathrm{~cm}$ as compared to a row spacing of $30 \mathrm{~cm}$ and broadcasting it can be assumed that this can be mainly due to enhanced resource utilization, particularly higher amount of lighted captured by the canopy within narrow rows as compared to wider rows [26].

The intraspecific competition among individual wheat plants are more pronounced in broadcasting method as compared with narrow row-spacing (Table 2a,b,c, Fig. 1).

Table 2(a). Statistical parameters referring to height, spike number, spike length and number of spikelet of wheat (Saher 2006) grown with row-spacing $(15 \mathrm{~cm})$ in $1 \mathrm{~m}^{-2}$ sub-plots

\begin{tabular}{|c|c|c|c|c|c|c|}
\hline Parameter & Mean & Standard Error & Variance & Gini Coefficient & Skewness & Kurtosis \\
\hline Plant height (cm) 90 DAE & 71.84 & 1.71 & 93.68 & 0.036 & 1.14 & 1.63 \\
\hline Plant height (cm) 120 DAE & 79.39 & 1.15 & 70.51 & 0.030 & -0.17 & -0.04 \\
\hline No. of Spike 90 DAE & 9.40 & 0.92 & 27.08 & 0.155 & 0.82 & -0.04 \\
\hline No. of Spike 120 DAE & 12.79 & 0.76 & 30.97 & 0.125 & 0.004 & -0.62 \\
\hline Spike length (cm) 120 DAE & 7.67 & 0.07 & 3.85 & 0.071 & 0.13 & 0.96 \\
\hline No. of Spikelet 120 DAE & 30.40 & 0.37 & 96.31 & 0.090 & 0.05 & -0.08 \\
\hline
\end{tabular}

Note: spike length and numbers of spikelet were only measured at the final harvest (120 DAE)

Table 2(b). Statistical parameters referring to height, spike number, spike length and number of spikelet of wheat (Saher 2006) grown with row-spacing $(30 \mathrm{~cm})$ in $1 \mathrm{~m}^{-2}$ sub-plots

\begin{tabular}{|c|c|c|c|c|c|c|}
\hline Parameter & Mean & Standard Error & Variance & Gini Coefficient & Skewness & Kurtosis \\
\hline Plant height (cm) 90 DAE & 67.41 & 1.63 & 96.02 & 0.037 & -1.32 & 3.91 \\
\hline Plant height (cm) 120 DAE & 84.00 & 1.04 & 68.30 & 0.023 & 1.48 & 6.05 \\
\hline No. of Spike 90 DAE & 6.27 & 0.59 & 12.66 & 0.124 & 0.948 & 0.269 \\
\hline No. of Spike 120 DAE & 10.39 & 0.59 & 18.78 & 0.111 & 1.35 & 3.37 \\
\hline Spike length (cm) 120 DAE & 7.56 & 0.07 & 3.55 & 0.069 & -0.22 & 0.18 \\
\hline No. of Spikelet 120 DAE & 31.41 & 0.34 & 71.09 & 0.072 & -0.40 & 1.09 \\
\hline
\end{tabular}

Note: spike length and numbers of spikelet were only measured at the final harvest (120 DAE)

Table 2(c). Statistical parameters referring to height, spike number, spike length and number of spikelet of wheat (Saher 2006) grown with row-spacing (broadcasting method) in $1 \mathbf{m}^{-2}$ sub-plots

\begin{tabular}{|c|c|c|c|c|c|c|}
\hline Parameter & Mean & Standard Error & Variance & Gini Coefficient & Skewness & Kurtosis \\
\hline Plant height (cm) 90 DAE & 58.52 & 1.78 & 114.54 & 0.101 & 0.17 & 0.83 \\
\hline Plant height (cm) 120 DAE & 75.55 & 0.80 & 56.11 & 0.025 & 1.40 & 8.39 \\
\hline No. of Spike 90 DAE & 4.08 & 0.32 & 3.79 & 0.134 & 0.56 & -0.19 \\
\hline No. of Spike 120 DAE & 8.58 & 0.49 & 20.83 & 0.148 & 0.75 & 0.11 \\
\hline Spike length (cm) 120 DAE & 7.23 & 0.06 & 3.08 & 0.067 & -0.02 & -0.18 \\
\hline No. of Spikelet 120 DAE & 31.73 & 0.31 & 77.42 & 0.078 & -0.05 & 0.02 \\
\hline
\end{tabular}

Note: spike length and numbers of spikelet were only measured at the final harvest (120 DAE) 

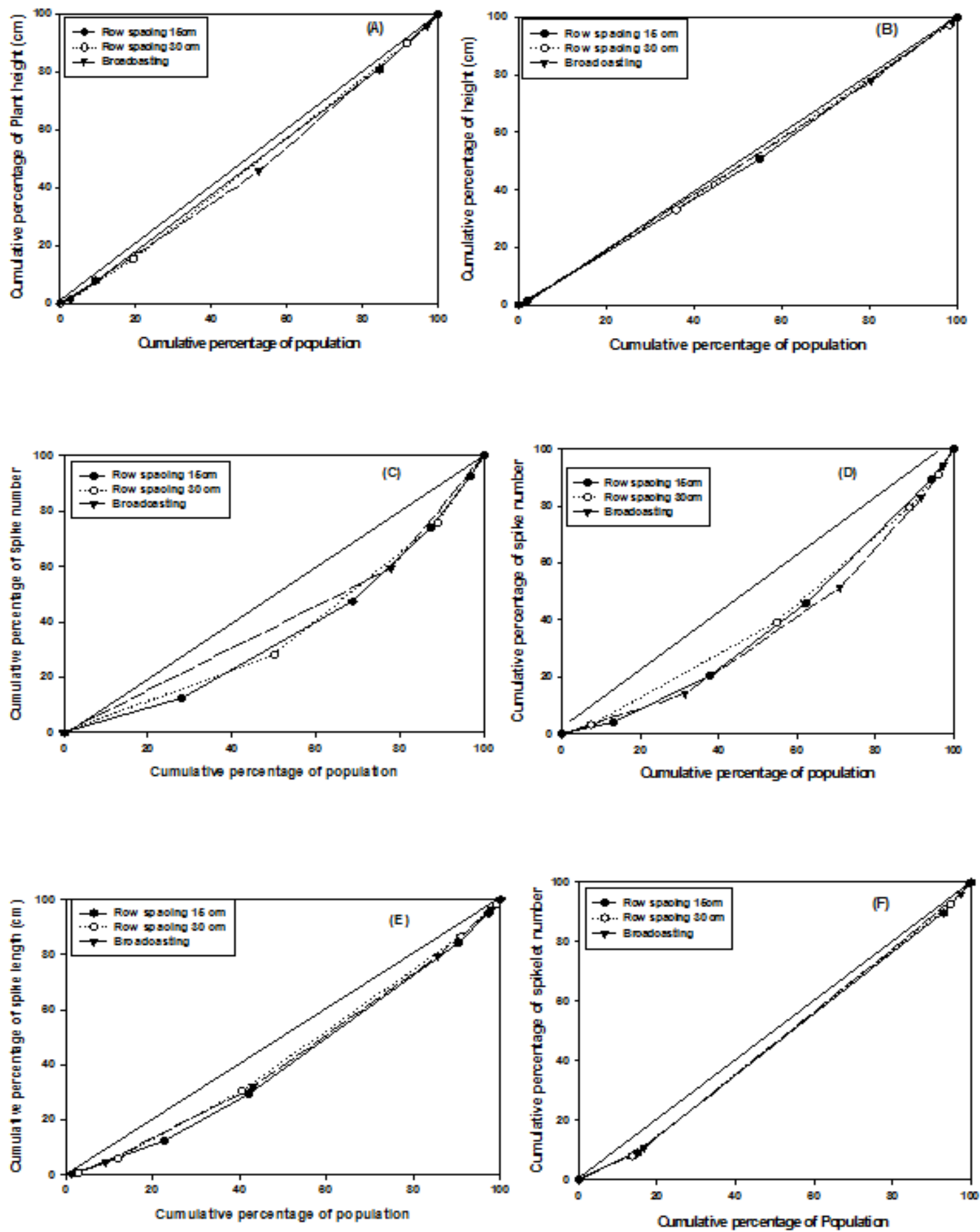

Figure 1. Lorenz curve (graphical presentation of Gini Coefficient, elaborating the area of in equality, i.e. the in equality among populations revealed in curve size in these figures) for wheat population: (A) plant height at $90 \mathrm{DAE}$, (B) plant height at 120 DAE, (C) spike numbers at 90 DAE, (D) spike number at 120 DAE, (E) spike length at $120 \mathrm{DAE}$, and (F) spikelet number at $120 \mathrm{DAE}$ 
The negative skewness value $(-0.17$ in plant height after 120 DAE in $15 \mathrm{~cm}$ row spacing), indicated that there were fewer smaller plants and majority were taller ones. This is may be due to the fact that at the end of growing season plants due to uniformity in space availability exhibited similar height. On other hand, kurtosis shows the distribution of variables and positive or negative values of kurtosis implied as the distribution is more peaked (leptokurtic) or bimodal (platykurtic). In case of plant height, distribution in three row-spacing was leptokurtic or more peaked compared with reproductive output that is more bimodal or platykurtic (Table 2a,b,c). On other hand the Gini values were very low in all row spacing which reflecting a very high size equality. The low Gini values also reflected in Lorenz curve except in number and length of spikes which mainly because inequality in time of maturity of reproductive biomass (Fig. 1), [19]. It is may be due to using a single wheat variety (Seher-2006) which showed uniformity in allocation of vegetative and reproductive biomass. The dissimilarities between skewed size distribution and size inequality (Gini coefficient and Lorenz curve) are mainly due to the contradictory concepts because according to Weiner and Solbrig; Weiner and Thomas [19, 26]. The skewness only interprets the fraction of large to small individuals and does not show the variation between individuals.

Application of Gini coefficient and Lorenz Curve are still not properly utilized in agricultural field and there is a potential of using these models particularly in case of inter-specific completion between two different crops as well as between weeds and crops. This is evident from the study that Gini coefficient and Lorenz Curve can easily estimate the critical period between crop and weed, which can be useful in determining increase or decrease in yield losses

\section{Conclusion}

Keeping in view, the mentioned facts and figures regarding were taken into account to study effect of intra specific competition on individual plants of "Sahar 2006" during the 2013-2014 wheat growing season in the experimental field at (LUAWMS). The effect of row spacing on agronomic characteristics of wheat showed non-significant response at the final harvest. However, application of Gini Coefficient and Lorenz Curve clearly indicated the inequalities in plant height, number and length of spike and spikelet among the individual plants. The Gini values are more pronounced at mid-season harvest compared with final harvest. The Sehar 2006 was showed non-significance response during last harvest at experiment field. Therefore, these outcomes conclude that intra-specific competition affects the final yield of Sehar-2006 variety in arid environments particularly in Lasbela district. Authors' contributions

Perceived and designed the experiments: $\mathrm{AH}$ Baloch, Performed the experiments: M Qadir \& N Muhammad, Analyzed the data: HU Rehman \& S Abdullah, Contributed materials/ analysis/ tools: AH Baloch \& HU Rehman, Wrote the paper: AH Baloch \& M Qadir, Revised the manuscript; HU Rehman \& S Abdullah.

\section{Acknowledgements}

This study was supported by Lasbela University of Agriculture, Water and Marine Sciences, Uthal, Balochistan. We would appreciate and acknowledge the support of Dr. Gul Hasan Baloch (Pro Vice Chancellor) and Mr. Amanullah Roonjha (Additional Registrar) during the research. The Moreover this we are also very grateful to the anonymous reviewers for their appreciated suggestions which supported us to present the refined version of this work.

\section{References}

1. Qadir M, Xuechun W, Baloch AH, Baloch IA, Azeem M, Imran M \& 
Saleem M (2018). The impact of drought on phenotypic characters of five advance bread wheat genotypes. Pure and Appl Biol 7 (2):2 635-642.

2. Mohammadi-Joo S, Mirasi A, Saeidiaboeshaghi R \& Amiri M (2015). Evaluation of bread wheat (Triticum aestivum L.) genotypes based on resistance indices under field conditions. Int J Biosci 6(2): 331-337.

3. Haider N (2012). Evidence for the origin of the B genome of bread wheat based on chloroplast DNA. Turk J Agric 36: 1325.

4. Shewry PR (2009). Drought on bread wheat crop. J of Experimental Bot 60(6): 1537-1553.

5. Monneveux $\mathrm{P}$, Jing $\mathrm{R} \&$ Misra SC (2012). Phenotyping for drought adaptation in wheat using physiological traits. Frontiers in Physiol 3: 429.

6. Farnham \& Dale E (2011). Row spacing, plant density, and hybrid effects on corn grain yield and moisture. Agronomy $J$ 93(5), 1049-1053.

7. Ghaffar A, Mahmood A, Yasir A, Muhammad N, Mahmood T, Munir MK \& Sattar A (2013). Optimizing seed rate and row spacing for different wheat cultivars. Crop Environ 4(1): 11-18.

8. Lemerle D, Gill GS, Murphy CE, Walker SR, Cousens RD, Mokhtari S \& Luckett DJ (2001). Genetic improvement and agronomy for enhanced wheat competitiveness with weeds. Aust $J$ of Agric Res 52(5): 527-548.

9. Cousens, Roger D, Allan G, Barnett \& Geoffrey CB (2003). Dynamics of competition between wheat and oat. Agron J 95(5): 1295-1304.

10. Vega CR \& Sadras VO (2003). Sizedependent growth and the development of inequality in maize, sunflower and soybean. Ann of Bot 91(7): 795-805.

11. Farooq AM, Yaqoob I \& Sadozai KN (2007). Varietal adoption effect on wheat crop production in irrigated areas of NWFP. Sarhad J Agric 23(3): 807814.

12. Ahmad M, Akram Z, Munir M \& Rauf $M$ (2006). Physio-morphic response of wheat genotypes under rainfed conditions. Pak J Bot 38(5): 1697-1702.

13. Directorate of crops and reporting services, Agriculture department, Qauetta, 2015-2016.

14. Alejandro dP, Iván M, María DS, José LA (2014). Agronomic and physiological traits associated with breeding advances of wheat under highproductive Mediterranean conditions. The Case of Chile, Environ and Exper Bot 103: 180-189

15. Hazoor AS, Zafar IK, Kafeel A, Yasar R \& Hafiz MT (2014). Human health hazards caused by heavy metals accumulation in wheat Variety Sehar2006 irrigated with domestic sewage water. Biologia (Pak) 60(1): 99-102

16. Zhou XB \& Chen YH (2011). Yield response of winter wheat to row spacing under irrigated and rainfed conditions. Bulgarian $J$ of Agric Sci 17(2): 158-166.

17. Ditommaso A \& Alan K Watson (1997). Effect of the fungal pathogen, Colletotrichum coccodes, on Abutilon theophrasti height hierarchy development. J of Appl Ecol 34(2): 518529.

18. Nagashima $\mathrm{H}$, Terashima I \& Katoh $\mathrm{S}$ (1995). Effects of plant density on frequency distributions of plant height in Chenopodium album stands: analysis based on continuous monitoring of height-growth of individual plants. Ann of Bot 75(2): 173-180.

19. Weiner J \& Solbrig OT (1984). The meaning and measurement of size hierarchies in plant populations. Oecologia 61(3): 334-336. 
20. Weiner J (1985). Size hierarchies in experimental populations of annual plants. Ecol 66(3): 743-752.

21. Shumway DL \& Koide RT (1995). Size and reproductive inequality in mycorrhizal and nonmycorrhizal populations of Abutilon theophrasti. $J$ of Ecol 613-620.

22. Dixon, Philip M \& et al. (1987). Bootstrapping the Gini coefficient of inequality. Ecol 68(5): 1548-1551.

23. Dixon PM (1993). The bootstrap and the jackknife: Describing the precision of ecological indices. Design and analysis of ecological experiments (ed. SM
Scheiner \& J Gurevitch). pp 290-318. London: Chapman \& Hall.

24. Chen C, Neill K, Wichman D \& Westcott M (2008). Hard red spring wheat response to row spacing, seeding rate, and nitrogen. Agron J 100(5): 1296-1302.

25. Auld BA, Kemp DR \& Medd RW (1983). "The influence of spatial arrangement on grain yield of wheat." Aust J of Agric Res 34(2): 99108.

26. Weiner J \& Thomas SC (1986). Size variability and competition in plant monocultures. Oikos, 211-222. 